\title{
Acute Viral Hepatitis B with a Severe Clinical Course in Pregnancy: A Case Report
}

\author{
Gebelikte Ciddi Seyirli Akut Viral Hepatit B: Olgu Sunumu
}

\author{
Ahmet UYANIKOĞLU1, Ferzan AYDIN1, Hacer UYANIKOĞLU2, Necati YENICE1 \\ ${ }^{1}$ Harran University Faculty of Medicine, Department of Gastroenterology, Şanlıurfa, Turkey \\ 2Harran University Faculty of Medicine, Department of Obstetrics and Gynecology, Şanlıurfa, Turkey
}

\begin{abstract}
The most common cause of non-pregnancy-specific acute hepatitis during pregnancy is hepatitis $\mathrm{B}$. The clinical course of viral hepatitis $B$ in pregnancy is similar to that in non-pregnant women, and about $1 \%$ of patients may develop acute liver failure. In this paper, we present a patient at 16 weeks of pregnancy who was administered tenofovirdisoproxil fumarate due to acute hepatitis B.

Keywords: Pregnancy, acute hepatitis B, tenofovir
\end{abstract}

öz

Gebelik esnasında ortaya çıkan ve gebeliğe özgü olmayan en sık akut hepatit nedeni viral hepatit B'dir. Gebelikte viral hepatit B hastalarını klinik seyri gebe olmayanlarla benzer olmasına karşın hastaların yaklaşık \%1'i akut karaciğer yetmezliğine ilerleyebilir. Bu yazımızda 16 haftalık gebeliği olan akut hepatit B hastasının takiplerinde ciddi seyirli olması üzerine tenofovir disoproksil fumarat başlanan bir hasta sunulmuştur. Anahtar Kelimeler: Gebelik, akut hepatit B, tenofovir

\section{Uyanıkoğlu A, Aydın F, Uyanıkoğlu H, Yenice N. Acute Viral Hepatitis B with a Severe Clinical Course in Pregnancy: A Case Report. Viral Hepat J. 2016;22:108-110.}

\section{Introduction}

Hepatitis $B$ virus (HBV) is a DNA virus that belongs to the Hepadnaviridae family. HBV infection is an important health issue leading to acute and chronic hepatitis, cirrhosis, and hepatocellular carcinoma in clinical course (1).

Sanlıurfa is in a HBV endemic region where birth rates increase each year (2). Pregnancy-specific liver diseases are responsible for approximately $60 \%$ of the liver diseases in pregnancy, whereas $40 \%$ of these diseases are caused by acute viral hepatitis $(3,4)$. The most common cause of jaundice is acute hepatitis B during pregnancy, and the treatment of acute infection is essentially as supportive (5). Antiviral therapy should be considered in patients with acute liver failure or severe chronic hepatitis (6). In this paper, we present a pregnant woman who was using tenofovir disoproxil fumarate due to acute hepatitis B.

\section{Case}

An 18-year-old pregnant woman was admitted to our gastroenterology department with the complaints of fatigue, yellowing of the skin, and itching. In history, she was at 16 weeks of pregnancy and itching and yellowing on her body was increased gradually in the past 2-3 days. She had no known any previous disease. Other systems were normal on physical examination. The laboratory findings were as follows: WBC: $12.300 / \mathrm{mcL}$, hemoglobin: $14.4 \mathrm{~g} / \mathrm{dL}$, platelet: $258.000 / \mathrm{mcL}$, urea: $8 \mathrm{mg} / \mathrm{dL}$, creatinine: $0.5 \mathrm{mg} / \mathrm{dL}$, aspartate aminotransferase: $2038 \mathrm{U} / \mathrm{L}$, alanine aminotransferase: $2223 \mathrm{U} / \mathrm{L}$, alkaline phosphatase: 183 $\mathrm{U} / \mathrm{L}$, gamma-glutamyltransferase: $45 \mathrm{U} / \mathrm{L}$, total bilirubin: $15.4 \mathrm{mg} /$ $\mathrm{dL}$, direct bilirubin: $10.4 \mathrm{mg} / \mathrm{dL}$, albumin: $3.4 \mathrm{~g} / \mathrm{dL}$, prothrombin time: 18.9 seconds, international normalized ratio (INR): 1.45, activated partial thromboplastin time: 32.8 seconds, sodium: 134 $\mathrm{mEq} / \mathrm{L}, \mathrm{K}: 3.3 \mathrm{mEq} / \mathrm{L}, \mathrm{P}: 2.6 \mathrm{mg} / \mathrm{dL}$, and C-reactive protein: 0.87 $\mathrm{mg} / \mathrm{dL}$. Trace amounts of urobilinogen, bilirubin in urine tests: was $(++)$. Patient's viral serology were: hepatitis B surface antigen $(\mathrm{HBsAg})(+)$, anti-Hbs (-), anti-hepatitis $\mathrm{C}$ virus $(\mathrm{HCV})(-)$, anti-HBc, immunoglobulin (lg) $\mathrm{G}(+)$, anti-HBc $\operatorname{lgM}(+)$, anti-hepatitis $A$ virus (HAV) IgG (+), anti-HAV IgM (-), anti-HDV (-), HBV-DNA:1,27×106 IU. Ultrasonographic examination showed that the fetus was 
alive at the $16^{\text {th }}$ week of gestation. The patient was hospitalized with the diagnosis of acute hepatitis B. She was hydrated and her liver function tests were monitored daily. During monitoring, there was an increase in INR and total bilirubin (2.01, $19.4 \mathrm{mg} /$ $\mathrm{dL}$, respectively). Hence, severe acute hepatitis $\mathrm{B}$ was considered and tenofovir $245 \mathrm{mg} 1 \times 1$ was started. Because the liver function tests were decreased after treatment, the patient discharged with follow-up recommendation.

\section{Discussion}

Although pregnancy-specific liver diseases are more common in pregnant women who present with acute hepatitis, acute viral hepatitis should be considered in the differential diagnosis particularly in endemic regions $(7,8)$. The differential diagnosis of liver diseases in pregnancy and starting treatment without delay is very important in terms of morbidity and mortality in both mother and baby. In our case, the patient had no characteristic history. The complaints of jaundice and pruritus indicated a pregnancy-specific liver disease at first. The patient's physical examination and abdominal ultrasonography were normal except for jaundice and $1 \mathrm{~cm}$ hepatomegaly. Transaminases were increased more than 10-fold, and the patient was diagnosed with acute hepatitis $\mathrm{B}$ upon detection of $\mathrm{HBsAg}(+)$, anti-HBsAg $(-)$, anti-HCV (-), anti-HBc-lgM (+), and anti-HBc-lgG (+) in the viral serology.

The treatment of acute hepatitis B is supportive (9). Acute HBV infection becomes chronic in $5-10 \%$ of adults, and approximately $1 \%$ of patients may develop acute liver failure (10). In a study, 22 pregnant women were compared with 87 non-pregnant women with acute HBV infection and no difference was found between the two groups in terms of risk of fulminant hepatic failure (11). In another study investigating the etiologic causes of fulminant hepatic failure in 52 pregnant patients, the most common cause was found to be acute hepatitis B following hepatitis E (10). Antiviral therapy should be considered in patients with acute liver failure and severe chronic hepatitis (9). Our patient was considered as having acute hepatitis B in the second trimester, and was hospitalized and followed up. In follow-up, bilirubin and prothrombin levels were increased progressively, thus, severe hepatitis B was considered and an antiviral treatment was started.

The perinatal transition rate has been reported to be $10 \%$ (12) in early acute hepatitis B, whereas this rate was reported as $60 \%$ (5) in the time of delivery. If the mother has high serum HBV DNA levels before the delivery, antiviral treatment should be considered to reduce viral load in the mother $(13,14)$. Tenofovir disoproxil fumarate (245 mg/day) or lamivudine (100 mg/day) are recommended for antiviral treatment and both drugs can be used safely during pregnancy $(9,15)$. Since the risk of resistance is low, tenofovir disoproxil fumarate should be preferred (16). In our series of 296 HBsAg-positive patients whom we followed between Dec 2011 and Apr 2012 in the Sanlıurfa region, there were 7 pregnant patients (approximately $2 \%$ ), and tenofovir was started in 3 of these patients in the last trimester because of the higher viral load (2). In our patient, severe hepatitis B was considered and tenofovir disoproxil fumarate therapy was started. Since the liver function test values were decreased after treatment, the patient discharged on follow-up recommendations.

\section{Conclusion}

Acute hepatitis B might be seen during pregnancy. These patients should be strictly followed for acute liver failure and antiviral treatment should be administered if necessary.

\section{Ethics}

Informed Consent: It was taken.

Peer-review: Externally and Internally peer-reviewed.

\section{Authorship Contributions}

Surgical and Medical Practices: Ahmet Uyanıkoğlu, Concept: Ahmet Uyanıkoğlu, Design: Ahmet Uyanıkoğlu, Data Collection or Processing: Ferzan Aydın, Ahmet Uyanıkoğlu, Analysis or Interpretation: Ahmet Uyanıkoğlu, Literature Search: Hacer Uyanıkoğlu, Ahmet Uyanıkoğlu, Necati Yenice, Writing: Ahmet Uyanıkoğlu, Hacer Uyanıkoğlu.

Conflict of Interest: No conflict of interest was declared by the authors.

Financial Disclosure: The authors declared that this study has received no financial support.

\section{References}

1. Koziel MJ, Siddiqui A. Hepatitis B Virus and Hepatitis Delta Virus. In: Mandell GL, Bennet JE, Dolin R (eds). Principles and Practice of Infectious Diseases. 6th ed. Philadelphia: Elsevier Churchill Livingstone; 2005; p. 1864-1890.

2. Uyanıkoğlu A, Sert U, Çetin B, Uyanıkoğlu H, Yenice N. The Distribution Clinical and Demographic Features of HBsAg Positive Patients in Şanlıurfa Region. Viral Hepat J. 2015;21:89-93.

3. Lee NM, Brady CW. Liver disease in pregnancy. World $J$ Gastroenterol. 2009;15:897-906

4. Rahman TM, Wendon J. Severe hepatic dysfunction in pregnancy. QJM. 2002;95:343-357.

5. Sookoian S. Liver disease during pregnancy: acute viral hepatitis Ann Hepatol. 2006;5:231-236.

6. Degertekin B, Lok AS. Indications for therapy in hepatitis B. Hepatology. 2009;49(5 Suppl):129-137.

7. Jaiswal SP, Jain AK, Naik G, Soni N, Chitnis DS. Viral hepatitis during pregnancy. Int J Gynaecol Obstet. 2001;72:103-108.

8. Özdemir S, Akın P. Gebelikte karaciğer hastalıkları. Cerrahpaşa J Med. 2004;35:131-139.

9. Potthoff A, Rifai $K$, Wedemeyer $H$, Deterding K, Manns $M$, Strassburg C. Successful treatment of fulminant hepatitis B during pregnancy. Z Gastroenterol. 2009;47:667-670.

10. Liang TJ. Hepatitis B: the virus and disease. Hepatology. 2009;49(5 Suppl):13-21.

11. Han YT, Sun C, Liu CX, Xie SS, Xiao D, Liu L, Yu JH, Li WW, Li Q. Clinical features and outcome of acute hepatitis B in pregnancy, BMC Infect Dis. 2014;14:368

12. Jonas MM. Hepatitis $B$ and pregnancy: an underestimated issue. Liver Int. 2009;29:133-139.

13. Günșar F. Gebelik ve Hepatit B Virüs Enfeksiyonu. Güncel Gastroenteroloji. 2012;16:299-302.

14. Terrault NA, Bzowej NH, Chang KM, Hwang JP, Jonas MM Murad MH; American Association for the Study of Liver Diseases. AASLD guidelines for treatment of chronic hepatitis B. Hepatology. 2016;63:261.

15. Chen $\mathrm{HL}$, Lee $\mathrm{CN}$, Chang $\mathrm{CH}$, Ni $\mathrm{YH}$, Shyu MK, Chen $\mathrm{SM}$, Hu $\mathrm{JJ}$, Lin $\mathrm{HH}$, Zhao LL, Mu SC, Lai MW, Lee CL, Lin HM, Tsai MS, Hsu JJ, Chen DS, Chan KA, Chang MH; Taiwan Study Group for the Prevention of Mother-to-Infant Transmission of 
HBV (PreMIT Study); Taiwan Study Group for the Prevention of Mother-to-Infant Transmission of HBV PreMIT Study. Efficacy of maternal tenofovir disoproxil fumarate in interrupting mother-to-infant transmission of hepatitis B virus. Hepatology. 2015;62:375-386
16. Pan $C Q$, Duan ZP, Dai EH, Zhang SQ, Rong Han R, Wang Y, Zhang $\mathrm{HH}$, Zou HB, Zhu BS, Zhao WJ, Xiu Jiang H; and the Study Group for the Mother-to-Child Transmission of Hepatitis B in China. Tenofovir Disoproxil Fumarate Reduces Perinatal Transmission of Hepatitis B Virus in Highly Viremic Mothers: A Multicenter Randomized Controlled Study. AASLD 2015. San Francisco, 2015. 